IZA DP No. 4878

Family Location and Caregiving Patterns from an International Perspective

Helmut Rainer

Thomas Siedler

April 2010 


\title{
Family Location and Caregiving Patterns from an International Perspective
}

\author{
Helmut Rainer \\ Ifo Institute, University of Munich \\ Thomas Siedler \\ DIW Berlin, University of Essex \\ and IZA
}
Discussion Paper No. 4878
April 2010

IZA

P.O. Box 7240

53072 Bonn

Germany

Phone: +49-228-3894-0

Fax: +49-228-3894-180

E-mail: iza@iza.org

Any opinions expressed here are those of the author(s) and not those of IZA. Research published in this series may include views on policy, but the institute itself takes no institutional policy positions.

The Institute for the Study of Labor (IZA) in Bonn is a local and virtual international research center and a place of communication between science, politics and business. IZA is an independent nonprofit organization supported by Deutsche Post Foundation. The center is associated with the University of Bonn and offers a stimulating research environment through its international network, workshops and conferences, data service, project support, research visits and doctoral program. IZA engages in (i) original and internationally competitive research in all fields of labor economics, (ii) development of policy concepts, and (iii) dissemination of research results and concepts to the interested public.

IZA Discussion Papers often represent preliminary work and are circulated to encourage discussion. Citation of such a paper should account for its provisional character. A revised version may be available directly from the author. 
IZA Discussion Paper No. 4878

April 2010

\section{ABSTRACT}

\section{Family Location and Caregiving Patterns from an International Perspective*}

This paper conducts a cross-national econometric analysis of intra-family location and caregiving patterns. First, we assess, from an international perspective, the relationship between family structure and the geographic proximity between adult children and their parents. We then examine whether differences in family structure affect the amount of informal care adult children provide to their elderly parents. Lastly, we look for cross-country differences in family location and caregiving patterns, and interpret observed differences in terms of heterogenous institutional solutions to the long-term care problem. Our results not only provide a new empirical perspective on the geography of the family, but also give interesting insights into how family-related and institutional factors shape patterns of time transfers from adult children to elderly parents.

JEL Classification: D19, J14

Keywords: geography of the family, child-to-parent time transfers

Corresponding author:

Helmut Rainer

Ifo Institute for Economic Research

University of Munich

Poschingerstrasse5

81679 Munich

Germany

E-mail: RAINER@ifo.de

\footnotetext{
*We would like to thank Helena Holmlund, Marco Faravelli, Rod McCrorie, and Georg Weizsäcker for their helpful comments on earlier drafts of this paper.
} 


\section{Introduction}

In a thought-provoking paper published recently, Kai A. Konrad et al. (2002) coined the notion of the "geography of the family". Their starting point is the observation that in many families, when parents grow old, the problem of taking care of the elderly emerges. Adult children care about the well-being of their parents, but make irreversible location decisions long before the care is needed. These decisions are key determinants of the cost of contributing to parental care. In families with more than one child, the well-being of elderly parents is a public good, and caregiving becomes a contribution game played between siblings. Adult children may, therefore, take strategic steps to alter their costs as contributors to their parents' care before their parents age and the need for assistance arises. Konrad et al. (2002) argue that firstborn siblings may have a first-mover advantage and may choose to raise their costs as contributors to care by locating at some critical distance from their parents. Second-born siblings are, thereby, forced to stay close to their parents and to provide all the care in the later contribution game. This precommitment strategy adopted by older siblings - similar to the idea of "burning bridges" (Schelling, 1980) - generates a geography of the family whereby firstborn children consistently locate further away from their parents than second-born or only children. Empirical evidence, based on data drawn from the German Ageing Survey, shows that adult children's location choices are in line with this prediction.

This paper takes these theoretical ideas and empirical results as its starting point and conducts a cross-national econometric analysis of intrafamily location and caregiving patterns. The analysis has three aims. First, we assess, from an international perspective, the relationship between family structure and the geographic proximity between adult children and their parents. We should be clear that with the term family structure we refer, in this paper, to the presence of a sibling, birth order, and sibship sex composition. Second, we examine whether differences in family structure affect the amount of informal care provided by adult children to their elderly parents. Third, we look for cross-country differences in family location and caregiving patterns, and interpret observed differences in terms of heterogenous institutional solutions to the long-term care problem. For example, if the public sector plays a minor role in caring for the elderly, family background might be expected to be an important factor in determining the location and caregiving choices of adult children. Conversely, if the care responsibilities of the public sector are well defined and explicit, family structure should, theoretically, play a relatively minor role.

Looking at the role and impact of family structure ties in well with more general debates about the impact of current demographic changes on future generations. It is 
well understood that the ageing of populations and the growing trend towards one-child families in many industrialized countries place many adult children in an unprecedented situation with respect to parent-care activities. Indeed, more and more adult children are likely to have at least one parent who survives into old age but no sibling with whom to share caregiving responsibilities. Should we, as a consequence, expect future generations to constrain their mobility decisions because of eldercare obligations? And if so, could this have additional consequences for the earnings potential of individuals in small families? An answer to these questions requires, first of all, an understanding of whether and how family structure affects the location and caregiving choices of adult children.

The data we use in this study comes from the Survey of Health, Ageing and Retirement in Europe (SHARE). This is a cross-national database which provides micro data on health, socio-economic status and the social and family networks of elderly individuals. We restrict our sample to parents with one or two biological children. Our estimation sample comprises roughly 10,000 individuals in 10 countries representing various regions in Europe, ranging from Scandinavia (Sweden, Denmark) through Central Europe (Austria, France, Germany, Belgium, the Netherlands) to the Mediterranean (Spain, Italy, Greece). Our empirical analysis exploits the substantial variation across families in terms of presence of a sibling, birth order, and sibship sex composition. We also exploit the fact that informal and formal care systems for the support of the elderly are different from country to country. This allows us to examine how family structure and institutional background interact in affecting location and caregiving patterns in families.

Overall, our results provide a new empirical perspective on the geography of the family. They also give novel insights into how family-related factors shape patterns of caregiving to ageing parents. Particularly worth mentioning are the following five findings: first, regression results for the majority of individual countries and the pooled cross-country sample suggest that the single most influential family-related factor determining intra-family location patterns is the presence of a sibling. Indeed, for most countries we consistently find that children with a sibling are significantly more likely to live further away from their elderly parents than only children. For example, our pooled country analysis shows that adult children with a sibling have a 5 percentage point higher probability of living more than 100 kilometres away from their parents than only children. Second, in line with the family location pattern just described, we also find evidence that actual time transfers to elderly parents are significantly lower among siblings than among only children. Third, while children with siblings appear to behave intrinsically differently than only children, there is no significant asymmetry in the behavior of firstborn and second-born siblings in 
terms of their location decisions and time transfers to their elderly parents. Fourthly, the gender composition of sibships has no discernable effect on location choices and patterns of caregiving to older parents. Finally, we show that cross-country differences in institutional solutions to the elderly care problem are reflected in family location and caregiving patterns. Indeed, in countries where the care responsibilities of the public sector are well defined and explicit, family structure has no significant effect on the location and caregiving choices of adult children. In contrast, where adult children have legal maintenance responsibilities towards their parents, different configurations of family size significantly influence the patterns of mobility and caregiving of adult children.

Taken together, these results are at odds with the view that older siblings may use their location choices to force younger siblings into staying close to their parents and providing the lion's share of care. What we find is that the presence of a sibling matters more for location and caregiving choices than birth order. This result may be due to a number of factors. First, in addition to the birth order effect described by Konrad et al. (2002), there may be other strategic aspects of family life. Rainer and Siedler (2009) build a simple model in which adult siblings compete in location and employment decisions so as to affect the balance of bargaining power in family care decisions. This, in turn, leads to a location equilibrium in which both firstborn and second-born siblings have a strategic incentive to move away from their parents. Second, if parents need a given amount of care, two siblings may find ways of sharing the responsibility, whereas an only child has to provide the whole amount. As a consequence, locating close to parents is more salient for the only child than for each of the siblings. Lastly, the cost of moving away from parents may be higher for only children than for children with siblings. For example, it is conceivable that siblings who move to the same area can still get together and tap into each other's social networks, reducing the cost of integration.

The remainder of this paper is organized as follows: the next section describes the data we use and provides some institutional background to elderly care in European countries. Section three presents the empirical results. Section four offers some concluding comments.

\section{Data}

Our main analysis is based on data drawn from the Survey of Health, Ageing and Retirement in Europe (SHARE). This cross-national database provides micro data on health, socio-economic status and the social and family networks of individuals aged 50 or over. Our estimation sample is based on data contributed by ten countries. They are a balanced 
representation of the various regions in Europe, ranging from Scandinavia (Sweden, Denmark) through Central Europe (Austria, France, Germany, Belgium, the Netherlands) to the Mediterranean (Spain, Italy, Greece). ${ }^{1}$ For our purposes, SHARE has three advantages. First, it collects detailed information on child-parent geographic proximity and socioeconomic characteristics for both generations. Second, it allows us to examine the determinants of geographical distances to parents across countries with large cultural, historical and political differences. Third, it not only helps us understand family location patterns, but also the extent to which time transfers to elderly parents are consistent with those location patterns.

We restrict our sample to parents with one or two biological children who are still alive at the time of the interview. We also require that all children are 30 years of age or older. On average, adult children are 42 years old, 65 percent are married, and slightly more than 70 percent of them have children themselves. Similar to the data set used by Konrad et al. (2002), children's socioeconomic characteristics and child-parent geographic distance are reported by the parent. The mean age of parents is 70 years, 60 percent of respondents are female and 15 percent report to have severely limiting health conditions. Overall, the sample consists of 9,707 adult children, 23 percent of whom are only children. A description of all variables used in the analysis, as well as summary statistics, are provided in the appendix.

To examine the location choices of adult children, we distinguish between the following five child-parent geographic distance categories: in the same house or household, less than 1 kilometre away, 1 to 5 kilometres away, 5 to 100 kilometres away, and more than 100 kilometres away. Overall, around 14 percent of adult children live in the same house or household as their elderly parents and 16 percent live more than 100 kilometres away from their parents' residence.

To analyze time allocations to elderly parents, we use two outcome variables. The first, Help to Parents, is a binary variable which equals one for children who have provided help to their parents in the twelve months prior to the interview. Services provided may include personal care (e.g., assistance with dressing, bathing, eating), practical household help (e.g., home repairs, gardening, shopping) and help with paperwork (e.g., completing forms, settling financial matters). The second, Frequency of Help, is a categorial variable

\footnotetext{
${ }^{1}$ This paper uses release 2.0.1 of the SHARE 2004 wave. The original SHARE data covers 12 countries. We decided not to report results for Switzerland because of relatively small sample sizes. Moreover, to guarantee a certain degree of homogeneity along economic, social and political dimensions, we excluded Israel from the analysis. Robustness checks indicated that the inclusion of these two countries does not alter our key results. For further information about SHARE see Börsch-Supan et al. (2005) and references therein.
} 
which provides information on whether a particular child has helped his or her parents almost daily, almost every week, almost every month, or less frequently.

Finally, we also made it our aim to investigate whether family location and caregiving patterns are shaped by cross-country differences in institutional features of elderly care systems. We, therefore, divide countries into three broad categories according to the extent of family obligations, legal requirements and public sector provision of elderly care (Miller and Warman, 1996). In the first category we sort autonomy countries. These are countries where family members have no legal obligation to provide or pay for elderly care. At the same time, the care responsibilities of the state are well defined and explicit. In Sweden, for example, the 1956 Municipality Social Services Act assigns local authorities the primary responsibility for elderly care. In our sample, the two countries that fall in this category are Denmark and Sweden. The second category is comprised of nuclear family countries. Here, family obligations are mainly defined as being based on the nuclear family, i.e., obligations between partners and between parents and children. In nuclear family countries, adult children have legal maintenance obligations towards their parents. In our sample, the countries that fall in this category are Austria, Belgium, France, Greece, Luxembourg and the Netherlands. Finally, the third category is made up of extended family countries. In these countries, extended families play an important role in providing intra-family support. This includes legal obligations between family members to provide financial support to each other and these obligations are embedded into a broader family context, including grandparents, uncles and aunts. In our sample, the two countries that fall into this category are Italy and Spain.

\section{Results}

\section{A. Family Location Patterns}

As noted above, the term "geography of the family" was coined to suggest that the main location pattern in families is characterized by asymmetric behavior of siblings, with firstborn children consistently locating further away from their parents than secondborn or only children (Konrad et al., 2002). However, it would also make theoretical sense to argue that what matters more than birth order is the very presence of a sibling. First, the strategic influence of siblings on one another in the choice of locations may override the strategic influence of firstborn on second-born siblings (Rainer and Siedler, 2009). Second, being an only child may necessitate shorter distances to parents since there are no other siblings who could help in if required. Conversely, having a sibling may allow the responsibility of caregiving to be shared between two people, possibly decreasing 
individual involvement and allowing for greater mobility. Finally, the cost of moving away from parents may be higher for only children than for children with siblings. For example, siblings who move to the same area can still socialize with and support each other.

We now attempt to shed light on these contradictory views by estimating ordinal logistic regressions for child-parent geographic distance. The results are reported in Table 1. The first column reports estimated coefficients from a pooled regression for all ten countries, and the remaining columns display the results for each country separately. Besides controlling for socioeconomic background variables, the pooled country regression also includes country dummy variables to capture country fixed effects on adult children's location decisions. To test for the presence of asymmetry in the location choice of firstborn and second-born siblings, we also report $p$-values from chi-square equality tests at the bottom of the table. The underlying null hypothesis here is that the estimated coefficients of being a firstborn and second-born on child-parent geographic distance are not statistically different from each other.

The main coefficients of interest are those on being a firstborn and a second-born sibling, respectively. Overall, having a sibling appears to have a profound impact on adult children's location decisions. There is, however, no evidence to relate birth order to asymmetric location choices of siblings. To see this, consider, first, the results from our pooled multi-country regression [column (1)]. The estimated coefficients suggest that both firstborn and second-born siblings are significantly more likely to live further away from their elderly parents than only children. The estimates are not only statistically significant at the 1 percent level; the corresponding marginal effects lead one to believe that they are also quantitatively important. For example, firstborns have a 5 percentage point and second-born siblings a 4 percentage point higher probability of living more than 100 kilometres away from their parents than only children. Finally, there is no significant asymmetry in the location choice of firstborn and second-born siblings. Indeed, the $p$ value of 0.31 reported at the bottom of the table indicates that the coefficients for first and second-born siblings are not statistically different from one another.

Moving on to individual country results [columns (2) to (11)], the family location pattern observed in the aggregate is borne out with a striking degree of consistency. The estimates for Italy, Spain, Germany, Austria, Greece and Belgium indicate that children with a sibling live, on average, further away from their parents than only children. ${ }^{2}$ While the presence of a sibling appears to play an important role for adult children's location choices, there is a lack of a birth order effect since the coefficients for firstborn and

\footnotetext{
${ }^{2}$ Note, however, that the coefficient of being a firstborn sibling in Germany is not precisely estimated.
} 
second-born siblings are generally not significantly different from each other. Indeed, the only coefficients the magnitude of which are in line with the idea that siblings behave asymmetrically (as suggested by Konrad et al. (2002)) are those for Sweden. However, these estimates lack precision and are not statistically significant at conventional levels. Overall, the empirical results so far serve to breathe life into the model's prediction by Rainer and Siedler (2009) that the presence of a sibling is more important for family location patterns than birth order.

As emphasized in Section 2, there are considerable cross-country differences in the institutional features of elderly care systems across Europe. We now investigate whether these differences in family obligations and legal requirements are mirrored by adult children's location decisions. Table 2 reports estimates of ordered logistic regressions for child-parent geographic distance separately for the three country regimes. Results reported in the first column are from a pooled regression for the sample of extended family countries. It includes individuals resident in Italy and Spain, countries where the family plays an important role in providing intra-family support, where family ties are strong and where the family - rather than the market or the public sector - provides goods and services to other family members (Giuliano, 2007). The second column reports pooled regression estimates for nuclear family countries, in which family obligations are mainly defined as being between partners and between parents and children. The last column in Table 2 presents estimates for the autonomy countries Denmark and Sweden, where there are no legal obligations for adult children to pay for or to provide elderly care and where the responsibility of the state is well defined. Looking at the main coefficients of being a firstborn and second-born sibling reveals striking differences across the three country regimes. The presence of a sibling plays the most important role for adult children living in extended family countries. Indeed, the coefficients of being a firstborn and second-born sibling in column 1 of Table 2 are highly significant and quantitatively important. For example, the coefficient of 0.346 for being a firstborn implies that firstborn siblings have a 6 percentage point higher likelihood of living more than 100 kilometres away from their parents than only children. The corresponding marginal effect for second-born siblings is 5 percentage points. These are sizeable effects given that only around 10 percent of adult children in Italy and Spain live more than 100 kilometres away from their parents' residence. Similarly, in the sample of nuclear family countries, adult children with a sibling live, on average, further away from their parents than only children. Note, however, that the estimates are smaller in magnitude than the corresponding ones in column 1. The last column in Table 2 shows that - in autonomy countries - there is no signifi- 
cant relationship between being a firstborn and second-born and child-parent geographic distance. The magnitude of these coefficients is very small and they are not statistically different from zero. Indeed, the corresponding marginal effects are all very close to zero, indicating that family structure is of no importance for adult children's location decisions in countries where the public sector has explicit responsibilities for elderly care. Overall, the estimates in Table 2 provide robust support for the implication that the presence of a sibling plays a more important role in countries where elderly care is the responsibility of the family rather than the state.

Next, we investigate whether the location behavior of adult children varies depending on the birth order and sibship sex composition. Similar to Konrad et al. (2002), we distinguish between nine different child-type dummy variables: male siblings with a younger brother, male siblings with a younger sister, female siblings with a younger brother, female siblings with a younger sister, male siblings with an older brother, male siblings with an older sister, female siblings with an older brother, female siblings with an older sister, and only children. For convenience, we also call firstborns Alice and Adam, and second-born children Betty and Benjamin. Table 3 reports the estimates of the various child-type dummies on child-parent geographic distance. As in previous regressions, being an only child serves as the reference category. The first column in Table 3 presents the coefficient estimates from the pooled multi-country regression. All eight child-type estimates are positive and statistically significant at the 1 percent level. In terms of the magnitude of the effects, these estimates indicate, for example, that being a male firstborn from a family with two sons (Adam of Adam-Benjamin) reduces the probability of living in the same house or household as the parents by four percentage points as compared to being an only child. Similarly, the corresponding marginal effect for a female firstborn from a family with two daughters (Alice of Alice-Betty) is also four percentage points. Hence, we again find support for our conjecture that the presence of a sibling is important for adult children's location choices irrespective of siblings' gender and sibship sex composition.

The estimates in columns (2) to (4) in Table 3 provide additional support for our hypothesis that the interplay between adult children's location decisions and family structure is shaped by institutional features. First, note that the majority of the estimated coefficients of child-type variables in column 2 of Table 3 are positive and statistically significant, and all estimates are considerably larger in magnitude than the corresponding ones in columns (3) and (4), respectively. Second, consistent with the results presented earlier, the coefficients on the various child type variables in the sample of nuclear family countries suggest that adult children with a sibling are significantly more likely to live 
further away from their parents than only children. This is equally true for sons and daughters, for both firstborn and second-born siblings and also holds independent of the presence of a brother or sister. Finally, again we do not find a strong relationship between family structure and child-parent geographic distance in the sample of autonomy countries-while most of the coefficient estimates for child-types are positive, none of them is statistically significant. Taken as a whole, the results provide evidence that birth order and sibling sex composition do not have a significant influence on adult children's location decisions, whereas the presence of a sibling matters for adult children's location decisions in countries where elderly care is mainly the responsibility of the family.

\section{B. Patterns of Time Transfers to Elderly Parents}

Our results so far show that, irrespective of birth order, children with a sibling systematically locate further away from their parents than only children. It is, therefore, not unreasonable to expect that the presence of both an older sibling or a younger sibling also reduces the time a particular child allocates to his or her parents. For instance, Ermisch (2009) reports a negative relationship between child-parent geographic distance and the likelihood that elderly parents receive regular or frequent in-kind help from their adult children. If, by contrast, older siblings can induce younger siblings to become the sole caregivers (à la Konrad et al., 2002), then the presence of a younger sibling would be negatively correlated with firstborn siblings' time transfers; conversely, second-born children's time allocation would be unaffected by the presence of an older sibling.

In an effort to understand the role of siblings in caring for elderly parents, we now turn to time transfers in the data. To this end, Table 4 presents estimates of the determinants of child-to-parent time allocations. Panel (a) reports the estimates as to whether adult children have provided any kind of help to their parents, and panel (b) displays the results for the frequency of help to elderly parents. Of primary importance are our findings concerning the effects of having a sibling. Overall, we find that time transfers to elderly parents respond negatively to the presence of a sibling. More specifically, the results in panel (a), column 1 indicate that having a sibling reduces the probability of a particular child providing any kind of help to his or her parents. As well as being statistically significant at the 1 percent level, this result is also quantitatively important. The corresponding marginal effects from the pooled regression suggest that being a firstborn or second-born sibling reduces the probability of providing help to parents by 4 percentage points, compared to being an only child. In line with our theory, the estimates suggest that the 
presence of a sibling is considerably more important than a birth order effect. ${ }^{3}$ Similarly, moving on to the individual country estimates reveal that both firstborn and second-born siblings are less likely to provide help to their parents than only children in all but one country (Belgium). The estimates in panel (b) show that children with a sibling provide less frequent help to their parents than only children. Non-reported marginal effects for the pooled cross-country estimates show, for example, that both types of siblings are 1 to 2 percentage points less likely to help their parent every week, compared to an only child.

The previous section demonstrated that, on average, adult siblings in nuclear family countries and autonomy countries locate further away from their parents' residence than only children. We now examine whether the institutional differences in the elderly care systems across European countries also have an impact on adult children's time transfers and support to ageing parents. The results are shown in Table 5. The first three columns present estimates for whether adult children have provided any kind of help to their parents, and the remaining columns present estimated coefficients for the frequency of help to elderly parents. There are several key findings: first, time transfers to parents respond negatively to the presence of a sibling in all six regressions, and the coefficients are always very precisely estimated and quantitatively important. For example, the estimated coefficients of being a firstborn (-1.008) and second-born (-0.943) in column 1 of Table 5 imply that siblings are 3 percentage points less likely to have provided help to their parents compared to only children. Second, consistent with children's location decisions, family structure is most strongly associated with time transfers to parents in extended family countries. However, distinct from the pattern we observed for adult children's location decisions, the estimates in Table 5 do not suggest that children in extended family countries provide more help to their parents than those in nuclear family countries.

In Table 6 we present estimates for the eight different child-types as to whether adult children have provided any kind of help to their elderly parents. Consistent with the previous results on child-parent geographic distance, the estimated coefficients in column 1 of Table 6 suggest that - independent of children's gender and sibling sex composition - both firstborn and second-born children are less likely to provide help to their elderly parents than only children. In other words, both firstborn male and firstborn female siblings, as well as second-born male and second-born female siblings are less likely to have helped their parents during the last year than only children. Moving on to the separate regime-type regressions shows that the negative relationship between family structure and

\footnotetext{
${ }^{3}$ While the p-value for the presence of asymmetry in providing help to parents for firstborn and secondborn siblings shows a statistically significant difference among siblings, the corresponding marginal effects do not point to important quantitative differences.
} 
the likelihood of providing help to elderly parents is strongest for adult children living in extended family countries. Note, for example, that four out of six estimated coefficients on child-types in column 2 of Table 6 are larger in magnitude than the corresponding ones in columns (3) and (4) of Table 6. Finally, the estimates on the frequency of help to elderly parents reported in Table 7 confirm these results.

It is worth emphasizing that the results just described hold both for first and secondborn siblings. In other words, birth order does not have a discernible impact on time transfers to elderly parents. This result resonates with our earlier findings concerning family location patterns. In particular, we have already empirically shown that the presence of an older sibling does not imply that younger siblings stay closer to their parents. In line with this lack of birth order effect, we have now observed that second-born children do not consistently assume the entire burden of making time transfers to their parents. These findings are important, as they suggest that there is no systematic asymmetry in the behavior of siblings. Rather, the results provide convincing evidence that the presence of a sibling matters, independent of birth order position, children's gender as well as siblings sex composition. Particularly persuasive, here, is the consistency of location and contribution patterns in families with one and two children across a wide range of countries.

\section{Conclusions}

The graying of populations is a growing concern worldwide, and policymakers around the globe place increasing pressure on families to provide care for the elderly. Families, and adult children, in particular, provide care to the elderly in a variety of ways. Some families do this via a network where more than one sibling takes responsibility for elderly parents. In other families, one adult child is the sole provider of care. Whether adult children form networks or one sibling provides the bulk of the care, conflict between siblings is a likely result of filial care. ${ }^{4}$ One frequently cited factor determining potential care contributions is the geographic proximity between caregivers and care recipients. This latter point means that the location decisions of parents and adult children are likely to be crucial for how sibling conflicts over caregiving are played out. It, therefore, makes theoretical sense to believe that the location and caregiving choices of adult children are intertwined decisions.

Against this background, we have carried out a cross-national empirical analysis of

\footnotetext{
${ }^{4}$ Sociological research suggests that nearly 40 percent of adult children providing care experienced serious conflict with a sibling, usually due to insufficient help.
} 
intra-family location and caregiving patterns. With this, we have made a contribution to the enrichment of our understanding of the geography of the family. We have also engaged with the question as to how family-related and institutional factors shape patterns of time transfers from adult children to elderly parents. The single most influential familyrelated factor determining intra-family location and caregiving patterns is the presence of a sibling, but only in countries where adult children have legal maintenance responsibilities towards their parents. Conversely, in countries where the elderly care responsibilities of the public sector are well defined and explicit, family structure has no significant effect on the location and caregiving choices of adult children. While children with siblings appear to behave intrinsically differently than only children, we find no evidence that birth order or the gender composition of sibships have a discernible effect on family location and caregiving patterns. In the next phase of empirical and theoretical research in this area, it will be interesting to see whether the geography of the family also has consequences for partnership formation decisions of adult children and their labor market outcomes.

\section{References}

Börsch-Supan, A., Hank, K. and Jürges, H. (2005). A new comprehensive and international view on ageing: Introducing the 'survey of health, ageing and retirement in europe. European Journal of Ageing, 2 (4), 245-253.

ERmisch, J. (2009). Adult child-parent relationships. In M. Brynin and J. Ermisch (eds.), Changing Relationships, Routledge: New York and London, pp. 127-145.

Giuliano, P. (2007). Living arrangements in western europe: Does cultural origin matter? Journal of the European Economic Association, 5 (5), 927-952.

Konrad, K. A., Künemund, H., Lommerud, K. E. and Robledo, J. R. (2002). Geography of the family. American Economic Review, 92 (4), 981-998.

Miller, J. and Warman, A. (1996). Family Obligations in Europe. Family Policy Studies Centre in Association with the Joseph Rowntree Foundation.

RAiner, H. and Siedler, T. (2009). O brother, where art thou? the effects of having a sibling on geographic mobility and labor market outcomes. Economica, 76 (303), $528-556$.

Schelling, T. C. (1980). The Strategy of Conflict. Harvard University Press. 
Table 1: Child-Parent Distance Regressions for Three Child Types

\begin{tabular}{|c|c|c|c|c|c|c|c|c|c|c|c|}
\hline & $\begin{array}{c}\text { All } \\
\text { countries }\end{array}$ & Italy & Spain & Germany & France & Austria & Greece & Belgium & $\begin{array}{c}\text { Nether- } \\
\text { lands }\end{array}$ & Sweden & Denmark \\
\hline \multicolumn{12}{|l|}{ Child } \\
\hline Age & $\begin{array}{c}0.013^{* *} \\
(0.003)\end{array}$ & $\begin{array}{l}0.022^{*} \\
(0.011)\end{array}$ & $\begin{array}{c}0.016+ \\
(0.010)\end{array}$ & $\begin{array}{c}0.011 \\
(0.009)\end{array}$ & $\begin{array}{l}0.018+ \\
(0.010)\end{array}$ & $\begin{array}{c}0.016 \\
(0.010)\end{array}$ & $\begin{array}{l}0.016^{*} \\
(0.008)\end{array}$ & $\begin{array}{c}0.013 \\
(0.008)\end{array}$ & $\begin{array}{l}0.023^{*} \\
(0.010)\end{array}$ & $\begin{array}{l}-0.007 \\
(0.009)\end{array}$ & $\begin{array}{c}0.016 \\
(0.014)\end{array}$ \\
\hline Female & $\begin{array}{l}-0.010 \\
(0.022)\end{array}$ & $\begin{array}{l}0.146^{*} \\
(0.071)\end{array}$ & $\begin{array}{c}-0.212^{* *} \\
(0.082)\end{array}$ & $\begin{array}{c}0.074 \\
(0.067)\end{array}$ & $\begin{array}{l}-0.051 \\
(0.073)\end{array}$ & $\begin{array}{c}0.015 \\
(0.074)\end{array}$ & $\begin{array}{l}-0.073 \\
(0.066)\end{array}$ & $\begin{array}{l}-0.022 \\
(0.063)\end{array}$ & $\begin{array}{l}-0.003 \\
(0.066)\end{array}$ & $\begin{array}{c}0.005 \\
(0.066)\end{array}$ & $\begin{array}{l}-0.104 \\
(0.091)\end{array}$ \\
\hline Married & $\begin{array}{c}0.267^{* *} \\
(0.027)\end{array}$ & $\begin{array}{c}0.505^{* *} \\
(0.101)\end{array}$ & $\begin{array}{c}0.478^{* *} \\
(0.150)\end{array}$ & $\begin{array}{c}0.248^{* *} \\
(0.079)\end{array}$ & $\begin{array}{c}0.281^{* *} \\
(0.088)\end{array}$ & $\begin{array}{c}0.039 \\
(0.087)\end{array}$ & $\begin{array}{c}0.688^{* *} \\
(0.109)\end{array}$ & $\begin{array}{c}0.122+ \\
(0.073)\end{array}$ & $\begin{array}{c}0.200^{*} \\
(0.083)\end{array}$ & $\begin{array}{l}0.168^{*} \\
(0.068)\end{array}$ & $\begin{array}{c}0.004 \\
(0.107)\end{array}$ \\
\hline Grandchildren & $\begin{array}{c}0.035 \\
(0.030)\end{array}$ & $\begin{array}{l}-0.009 \\
(0.094)\end{array}$ & $\begin{array}{c}0.410^{* *} \\
(0.139)\end{array}$ & $\begin{array}{c}-0.096 \\
(0.086)\end{array}$ & $\begin{array}{l}-0.081 \\
(0.107)\end{array}$ & $\begin{array}{l}-0.016 \\
(0.093)\end{array}$ & $\begin{array}{l}-0.133 \\
(0.113)\end{array}$ & $\begin{array}{c}0.361^{* *} \\
(0.086)\end{array}$ & $\begin{array}{c}0.131 \\
(0.088)\end{array}$ & $\begin{array}{l}-0.220^{*} \\
(0.098)\end{array}$ & $\begin{array}{l}-0.006 \\
(0.130)\end{array}$ \\
\hline Firstborn & $\begin{array}{c}0.200^{* *} \\
(0.029)\end{array}$ & $\begin{array}{c}0.392^{* *} \\
(0.097)\end{array}$ & $\begin{array}{l}0.261^{*} \\
(0.112)\end{array}$ & $\begin{array}{c}0.085 \\
(0.083)\end{array}$ & $\begin{array}{c}0.116 \\
(0.094)\end{array}$ & $\begin{array}{c}0.414^{* *} \\
(0.094)\end{array}$ & $\begin{array}{l}0.183^{*} \\
(0.092)\end{array}$ & $\begin{array}{c}0.252^{* *} \\
(0.080)\end{array}$ & $\begin{array}{c}-0.001 \\
(0.106)\end{array}$ & $\begin{array}{c}0.115 \\
(0.093)\end{array}$ & $\begin{array}{c}0.065 \\
(0.145)\end{array}$ \\
\hline Second-born & $\begin{array}{c}0.175^{* *} \\
(0.030)\end{array}$ & $\begin{array}{c}0.343^{* *} \\
(0.101)\end{array}$ & $\begin{array}{l}0.211+ \\
(0.118)\end{array}$ & $\begin{array}{l}0.161+ \\
(0.085)\end{array}$ & $\begin{array}{c}0.119 \\
(0.095)\end{array}$ & $\begin{array}{c}0.348^{* *} \\
(0.104)\end{array}$ & $\begin{array}{l}0.199^{*} \\
(0.094)\end{array}$ & $\begin{array}{l}0.169^{*} \\
(0.082)\end{array}$ & $\begin{array}{c}0.055 \\
(0.104)\end{array}$ & $\begin{array}{c}0.011 \\
(0.094)\end{array}$ & $\begin{array}{c}0.054 \\
(0.135)\end{array}$ \\
\hline \multicolumn{12}{|l|}{ Parent } \\
\hline Age & $\begin{array}{c}-0.010^{* *} \\
(0.003)\end{array}$ & $\begin{array}{l}-0.014 \\
(0.009)\end{array}$ & $\begin{array}{c}-0.020^{*} \\
(0.009)\end{array}$ & $\begin{array}{l}-0.003 \\
(0.008)\end{array}$ & $\begin{array}{c}-0.019^{*} \\
(0.009)\end{array}$ & $\begin{array}{c}-0.020^{*} \\
(0.009)\end{array}$ & $\begin{array}{l}-0.009 \\
(0.007)\end{array}$ & $\begin{array}{c}-0.018^{*} \\
(0.007)\end{array}$ & $\begin{array}{r}-0.014+ \\
(0.008)\end{array}$ & $\begin{array}{c}0.002 \\
(0.007)\end{array}$ & $\begin{array}{l}-0.001 \\
(0.013)\end{array}$ \\
\hline Female & $\begin{array}{c}-0.089^{* *} \\
(0.026)\end{array}$ & $\begin{array}{c}-0.231^{*} \\
(0.091)\end{array}$ & $\begin{array}{l}-0.056 \\
(0.107)\end{array}$ & $\begin{array}{c}-0.160^{*} \\
(0.075)\end{array}$ & $\begin{array}{l}-0.064 \\
(0.089)\end{array}$ & $\begin{array}{c}-0.250^{* *} \\
(0.093)\end{array}$ & $\begin{array}{l}-0.107 \\
(0.085)\end{array}$ & $\begin{array}{l}-0.088 \\
(0.075)\end{array}$ & $\begin{array}{c}0.000 \\
(0.080)\end{array}$ & $\begin{array}{l}-0.050 \\
(0.072)\end{array}$ & $\begin{array}{c}0.024 \\
(0.114)\end{array}$ \\
\hline Married & $\begin{array}{l}-0.000 \\
(0.028)\end{array}$ & $\begin{array}{l}-0.114 \\
(0.092)\end{array}$ & $\begin{array}{l}0.243^{*} \\
(0.107)\end{array}$ & $\begin{array}{c}0.000 \\
(0.084)\end{array}$ & $\begin{array}{c}0.075 \\
(0.086)\end{array}$ & $\begin{array}{l}-0.088 \\
(0.092)\end{array}$ & $\begin{array}{c}0.062 \\
(0.084)\end{array}$ & $\begin{array}{c}-0.214^{* *} \\
(0.081)\end{array}$ & $\begin{array}{c}0.021 \\
(0.087)\end{array}$ & $\begin{array}{l}-0.046 \\
(0.077)\end{array}$ & $\begin{array}{c}0.035 \\
(0.109)\end{array}$ \\
\hline Limited activities & $\begin{array}{l}0.015 \\
(0.027)\end{array}$ & $\begin{array}{l}-0.139 \\
(0.089)\end{array}$ & $\begin{array}{c}0.051 \\
(0.097)\end{array}$ & $\begin{array}{l}-0.013 \\
(0.076)\end{array}$ & $\begin{array}{l}-0.036 \\
(0.092)\end{array}$ & $\begin{array}{l}0.174+ \\
(0.089)\end{array}$ & $\begin{array}{c}0.114 \\
(0.078)\end{array}$ & $\begin{array}{l}-0.089 \\
(0.076)\end{array}$ & $\begin{array}{c}0.233^{* *} \\
(0.085)\end{array}$ & $\begin{array}{l}-0.003 \\
(0.077)\end{array}$ & $\begin{array}{l}-0.072 \\
(0.108)\end{array}$ \\
\hline $\begin{array}{l}\text { Severely } \\
\text { limited activities }\end{array}$ & $\begin{array}{l}-0.042 \\
(0.035)\end{array}$ & $\begin{array}{l}-0.073 \\
(0.108)\end{array}$ & $\begin{array}{l}-0.012 \\
(0.210)\end{array}$ & $\begin{array}{l}-0.076 \\
(0.098)\end{array}$ & $\begin{array}{l}-0.267^{*} \\
(0.117)\end{array}$ & $\begin{array}{c}0.079 \\
(0.124)\end{array}$ & $\begin{array}{l}0.198+ \\
(0.117)\end{array}$ & $\begin{array}{c}-0.339^{* *} \\
(0.089)\end{array}$ & $\begin{array}{c}0.143 \\
(0.102)\end{array}$ & $\begin{array}{c}0.083 \\
(0.100)\end{array}$ & $\begin{array}{l}-0.183 \\
(0.152)\end{array}$ \\
\hline $\mathrm{P}$-value of equality test $\mathrm{t}^{a}$ & 0.31 & 0.56 & 0.56 & 0.32 & 0.97 & 0.43 & 0.80 & 0.29 & 0.49 & 0.15 & 0.92 \\
\hline Pseudo $R^{2}$ & 0.05 & 0.04 & 0.06 & 0.05 & 0.04 & 0.04 & 0.03 & 0.04 & 0.06 & 0.01 & 0.02 \\
\hline Observations & 9,707 & 966 & 735 & 1,114 & 920 & 869 & 1,173 & 1,217 & 962 & 1,151 & 600 \\
\hline
\end{tabular}

Notes: The dependent variable is child-parent geographic distance. The reference categories for non-scaled variables are male, not married, no grandchildren, being an only child, male parent, unmarried parent, and parent has not been limited for the past six month because of a health problem in usual daily activities. Robust standard errors at the family level in parentheses. All regressions also control for a maximum set of highest educational degree variables for adult children and parents. The regression in column 1 also includes a maximum set of country dummy variables. ${ }^{a}$ Figures are p-values of the test that the estimated coefficients of being firstborn and second-born are equal and are obtained from $\chi^{2}$-statistics. + significant at 10 percent, ${ }^{*}$ significant at 5 percent, ${ }^{* *}$ significant at 1 percent level. 
Table 2: Institutional Heterogeneity in Child-Parent Distance Regressions

\begin{tabular}{|c|c|c|c|}
\hline & $\begin{array}{c}\text { Extended Family } \\
\text { Countries }\end{array}$ & $\begin{array}{c}\text { Nuclear Family } \\
\text { Countries }\end{array}$ & $\begin{array}{l}\text { Autonomy } \\
\text { Countries }\end{array}$ \\
\hline \multicolumn{4}{|l|}{ Child } \\
\hline \multirow[t]{2}{*}{ Age } & $0.018^{*}$ & $0.014^{* *}$ & 0.002 \\
\hline & $(0.007)$ & $(0.004)$ & $(0.007)$ \\
\hline \multirow[t]{2}{*}{ Female } & -0.002 & -0.008 & -0.024 \\
\hline & $(0.053)$ & $(0.027)$ & $(0.053)$ \\
\hline \multirow[t]{2}{*}{ Married } & $0.511^{* *}$ & $0.245^{* *}$ & $0.118^{*}$ \\
\hline & $(0.083)$ & $(0.033)$ & $(0.057)$ \\
\hline \multirow[t]{2}{*}{ Grandchildren } & $0.148+$ & 0.040 & $-0.160^{*}$ \\
\hline & $(0.077)$ & $(0.037)$ & $(0.077)$ \\
\hline \multirow[t]{2}{*}{ Firstborn } & $0.346^{* *}$ & $0.182^{* *}$ & 0.105 \\
\hline & $(0.072)$ & $(0.036)$ & $(0.078)$ \\
\hline \multirow[t]{2}{*}{ Second-born } & $0.286^{* *}$ & $0.179^{* *}$ & 0.033 \\
\hline & $(0.075)$ & $(0.037)$ & $(0.076)$ \\
\hline \multirow[t]{2}{*}{ Age } & $-0.016^{*}$ & $-0.011^{* *}$ & 0.002 \\
\hline & $(0.006)$ & $(0.003)$ & $(0.006)$ \\
\hline \multirow[t]{2}{*}{ Female } & $-0.146^{*}$ & $-0.092^{* *}$ & -0.028 \\
\hline & $(0.068)$ & $(0.033)$ & $(0.060)$ \\
\hline \multirow[t]{2}{*}{ Married } & 0.032 & -0.004 & -0.024 \\
\hline & $(0.070)$ & $(0.035)$ & $(0.063)$ \\
\hline \multirow[t]{2}{*}{ Limited activities } & -0.041 & 0.049 & -0.033 \\
\hline & $(0.065)$ & $(0.033)$ & $(0.062)$ \\
\hline \multirow[t]{2}{*}{ Severely limited activities } & -0.006 & -0.051 & -0.000 \\
\hline & $(0.096)$ & $(0.042)$ & $(0.084)$ \\
\hline P-value of equality test ${ }^{a}$ & 0.31 & 0.92 & 0.22 \\
\hline Pseudo $R^{2}$ & 0.04 & 0.04 & 0.01 \\
\hline Observations & 1,701 & 6,255 & 1,751 \\
\hline
\end{tabular}

Notes: The dependent variable is child-parent geographic distance. Extended family countries: Italy and Spain. Nuclear family countries: Germany, France, Austria, Greece, Belgium and the Netherlands. Autonomy countries: Sweden and Denmark. The reference categories for non-scaled variables are male, not married, no grandchildren, being an only child, male parent, unmarried parent, and parent has not been limited for the past six month because of a health problem in usual daily activities. Robust standard errors at the family level in parentheses. All regressions also control for a maximum set of highest educational degree variables for adult children and parents, and also include a maximum set of country dummy variables. ${ }^{a}$ Figures are p-values of the test that the estimated coefficients of being firstborn and second-born are equal and are obtained from $\chi^{2}$-statistics. + significant at 10 percent, ${ }^{*}$ significant at 5 percent, ${ }^{* *}$ significant at 1 percent level. 
Table 3: Sibship Sex Composition in Child-Parent Distance Regressions

\begin{tabular}{|c|c|c|c|c|}
\hline & All Countries & $\begin{array}{c}\text { Extended Family } \\
\text { Countries }\end{array}$ & $\begin{array}{c}\text { Nuclear Family } \\
\text { Countries }\end{array}$ & $\begin{array}{l}\text { Autonomy } \\
\text { Countries } \\
\end{array}$ \\
\hline \multicolumn{5}{|l|}{ Child } \\
\hline \multirow[t]{2}{*}{ Age } & $0.013^{* *}$ & $0.017^{*}$ & $0.014^{* *}$ & 0.002 \\
\hline & $(0.003)$ & $(0.007)$ & $(0.004)$ & $(0.007)$ \\
\hline \multirow[t]{2}{*}{ Female } & 0.024 & $0.217+$ & -0.036 & -0.011 \\
\hline & $(0.047)$ & $(0.121)$ & $(0.056)$ & $(0.128)$ \\
\hline \multirow[t]{2}{*}{ Married } & $0.267^{* *}$ & $0.503^{* *}$ & $0.245^{* *}$ & $0.122^{*}$ \\
\hline & $(0.027)$ & $(0.084)$ & $(0.033)$ & $(0.057)$ \\
\hline \multirow[t]{2}{*}{ Grandchildren } & 0.034 & $0.154^{*}$ & 0.039 & $-0.164^{*}$ \\
\hline & $(0.030)$ & $(0.076)$ & $(0.037)$ & $(0.077)$ \\
\hline \multirow[t]{2}{*}{ Adam of Adam-Benjamin } & $0.220^{* *}$ & $0.497 * *$ & $0.176^{* *}$ & 0.041 \\
\hline & $(0.051)$ & $(0.128)$ & $(0.061)$ & $(0.130)$ \\
\hline \multirow[t]{2}{*}{ Adam of Adam-Betty } & $0.259^{* *}$ & $0.535^{* *}$ & $0.177^{* *}$ & 0.202 \\
\hline & $(0.048)$ & $(0.117)$ & $(0.059)$ & $(0.125)$ \\
\hline \multirow[t]{2}{*}{ Alice of Alice-Betty } & $0.199^{* *}$ & $0.291^{* *}$ & $0.224^{* *}$ & 0.053 \\
\hline & $(0.048)$ & $(0.113)$ & $(0.059)$ & $(0.123)$ \\
\hline \multirow[t]{2}{*}{ Alice of Alice-Benjamin } & $0.129^{* *}$ & 0.092 & $0.157^{* *}$ & 0.104 \\
\hline & $(0.045)$ & $(0.112)$ & $(0.056)$ & $(0.114)$ \\
\hline \multirow[t]{2}{*}{ Benjamin of Adam-Benjamin } & $0.185^{* *}$ & $0.353^{* *}$ & $0.178^{* *}$ & 0.015 \\
\hline & $(0.051)$ & $(0.125)$ & $(0.063)$ & $(0.128)$ \\
\hline \multirow[t]{2}{*}{ Betty of Adam-Betty } & $0.151^{* *}$ & 0.128 & $0.214^{* *}$ & -0.027 \\
\hline & $(0.047)$ & $(0.112)$ & $(0.059)$ & $(0.113)$ \\
\hline \multirow[t]{2}{*}{ Betty of Alice-Betty } & $0.197^{* *}$ & $0.259^{*}$ & $0.207^{* *}$ & 0.141 \\
\hline & $(0.049)$ & $(0.120)$ & $(0.060)$ & $(0.119)$ \\
\hline \multirow[t]{2}{*}{ Benjamin of Alice-Benjamin } & $0.173^{* *}$ & $0.466^{* *}$ & $0.120^{*}$ & 0.029 \\
\hline & $(0.048)$ & $(0.126)$ & $(0.059)$ & $(0.125)$ \\
\hline \multicolumn{5}{|l|}{ Parent } \\
\hline \multirow[t]{2}{*}{ Age } & $-0.010^{* *}$ & $-0.015^{*}$ & $-0.011^{* *}$ & 0.002 \\
\hline & $(0.003)$ & $(0.006)$ & $(0.003)$ & $(0.006)$ \\
\hline \multirow[t]{2}{*}{ Female } & $-0.088^{* *}$ & $-0.141^{*}$ & $-0.091^{* *}$ & -0.027 \\
\hline & $(0.026)$ & $(0.069)$ & $(0.033)$ & $(0.060)$ \\
\hline \multirow[t]{2}{*}{ Married } & -0.000 & 0.037 & -0.004 & -0.024 \\
\hline & $(0.028)$ & $(0.070)$ & $(0.035)$ & $(0.063)$ \\
\hline \multirow[t]{2}{*}{ Limited activities } & 0.016 & -0.036 & 0.050 & -0.031 \\
\hline & $(0.027)$ & $(0.065)$ & $(0.033)$ & $(0.062)$ \\
\hline \multirow[t]{2}{*}{ Severely limited activities } & -0.041 & -0.009 & -0.050 & 0.004 \\
\hline & $(0.035)$ & $(0.096)$ & $(0.042)$ & $(0.084)$ \\
\hline Pseudo $R^{2}$ & 0.05 & 0.04 & 0.04 & 0.01 \\
\hline Observations & 9,707 & 1,701 & 6,255 & 1,751 \\
\hline
\end{tabular}

Notes: The dependent variable is child-parent geographic distance. Extended family countries: Italy and Spain. Nuclear family countries: Germany, France, Austria, Greece, Belgium and the Netherlands. Autonomy countries: Sweden and Denmark. The reference categories for non-scaled variables are male, not married, no grandchildren, being an only child, male parent, unmarried parent, and parent has not been limited for the past six month because of a health problem in usual daily activities. Robust standard errors at the family level in parentheses. All regressions also control for a maximum set of highest educational degree variables for adult children and parents, and also include a maximum set of country dummy variables. + significant at 10 percent, ${ }^{*}$ significant at 5 percent, ${ }^{* *}$ significant at 1 percent level. 
Table 4: Child-to-Parent Time Regressions for Three Child Types

\begin{tabular}{|c|c|c|c|c|c|c|c|c|c|c|c|}
\hline & $\begin{array}{c}\text { All } \\
\text { countries }\end{array}$ & Italy & Spain & Germany & France & Austria & Greece & Belgium & $\begin{array}{c}\text { Nether- } \\
\text { lands }\end{array}$ & Sweden & Denmark \\
\hline \multicolumn{12}{|l|}{ A. Help to parents } \\
\hline Firstborn & $\begin{array}{c}-0.544^{* *} \\
(0.060)\end{array}$ & $\begin{array}{c}-0.966^{* *} \\
(0.247)\end{array}$ & $\begin{array}{c}-1.057^{* *} \\
(0.276)\end{array}$ & $\begin{array}{c}-0.369^{*} \\
(0.144)\end{array}$ & $\begin{array}{c}-0.676^{* *} \\
(0.228)\end{array}$ & $\begin{array}{c}-0.739^{* *} \\
(0.194)\end{array}$ & $\begin{array}{c}-0.400^{*} \\
(0.168)\end{array}$ & $\begin{array}{c}-0.474^{*} \\
(0.185)\end{array}$ & $\begin{array}{c}-0.787^{* *} \\
(0.245)\end{array}$ & $\begin{array}{c}-0.754^{* *} \\
(0.180)\end{array}$ & $\begin{array}{c}-0.443^{*} \\
(0.217)\end{array}$ \\
\hline Second-born & $\begin{array}{c}-0.481^{* *} \\
(0.062)\end{array}$ & $\begin{array}{c}-0.926^{* *} \\
(0.274)\end{array}$ & $\begin{array}{c}-0.941^{* *} \\
(0.278)\end{array}$ & $\begin{array}{c}-0.354^{*} \\
(0.149)\end{array}$ & $\begin{array}{c}-0.522^{*} \\
(0.244)\end{array}$ & $\begin{array}{c}-0.558^{* *} \\
(0.177)\end{array}$ & $\begin{array}{c}-0.394^{*} \\
(0.173)\end{array}$ & $\begin{array}{l}-0.298 \\
(0.205)\end{array}$ & $\begin{array}{c}-0.729 * * \\
(0.233)\end{array}$ & $\begin{array}{c}-0.632^{* *} \\
(0.182)\end{array}$ & $\begin{array}{c}-0.488^{*} \\
(0.226)\end{array}$ \\
\hline $\mathrm{P}$-value of equality test ${ }^{a}$ & 0.02 & 0.76 & 0.28 & 0.82 & 0.12 & 0.03 & 0.92 & 0.05 & 0.60 & 0.15 & 0.64 \\
\hline Pseudo $R^{2}$ & 0.219 & 0.246 & 0.329 & 0.140 & 0.414 & 0.221 & 0.191 & 0.275 & 0.247 & 0.292 & 0.122 \\
\hline \multicolumn{12}{|l|}{ B. Frequency of help } \\
\hline Firstborn & $\begin{array}{c}-0.523^{* *} \\
(0.058)\end{array}$ & $\begin{array}{c}-1.000^{* *} \\
(0.249)\end{array}$ & $\begin{array}{c}-0.970^{* *} \\
(0.277)\end{array}$ & $\begin{array}{c}-0.320^{*} \\
(0.137)\end{array}$ & $\begin{array}{c}-0.578^{*} \\
(0.225)\end{array}$ & $\begin{array}{c}-0.729 * * \\
(0.181)\end{array}$ & $\begin{array}{c}-0.318^{*} \\
(0.159)\end{array}$ & $\begin{array}{c}-0.520^{* *} \\
(0.177)\end{array}$ & $\begin{array}{c}-0.777^{* *} \\
(0.245)\end{array}$ & $\begin{array}{c}-0.739^{* *} \\
(0.164)\end{array}$ & $\begin{array}{c}-0.444^{*} \\
(0.199)\end{array}$ \\
\hline Second-born & $\begin{array}{c}-0.463^{* *} \\
(0.059)\end{array}$ & $\begin{array}{c}-1.009^{* *} \\
(0.269)\end{array}$ & $\begin{array}{c}-0.824^{* *} \\
(0.272)\end{array}$ & $\begin{array}{c}-0.334^{*} \\
(0.136)\end{array}$ & $\begin{array}{c}-0.477^{*} \\
(0.235)\end{array}$ & $\begin{array}{c}-0.589^{* *} \\
(0.172)\end{array}$ & $\begin{array}{r}-0.313+ \\
(0.160)\end{array}$ & $\begin{array}{l}-0.297 \\
(0.194)\end{array}$ & $\begin{array}{c}-0.744^{* *} \\
(0.225)\end{array}$ & $\begin{array}{c}-0.559^{* *} \\
(0.173)\end{array}$ & $\begin{array}{l}-0.440^{*} \\
(0.221)\end{array}$ \\
\hline P-value of equality test ${ }^{a}$ & 0.02 & 0.95 & 0.25 & 0.85 & 0.25 & 0.09 & 0.94 & 0.01 & 0.74 & 0.06 & 0.97 \\
\hline Pseudo $R^{2}$ & 0.17 & 0.22 & 0.24 & 0.11 & 0.31 & 0.17 & 0.14 & 0.22 & 0.21 & 0.22 & 0.10 \\
\hline Observations & 6,741 & 591 & 460 & 795 & 729 & 597 & 693 & 826 & 731 & 887 & 432 \\
\hline
\end{tabular}

Notes: In Panel A the dependent variable is whether adult children have provided any kind of help to their parents in the last twelve months. In Panel B the dependent variable is the frequency of help to parents (five categories). Panel A reports estimates from probit regressions and Panel B reports estimates from ordered probit regressions. Non-reported explanatory variables as in Table 2, except of highest educational degree variables for adult children and parents in the country specific regressions due to collinearity problems. Robust standard errors at the family level in parentheses.

${ }^{a}$ Figures are p-values of the test that the estimated coefficients of being firstborn and second-born are equal and are obtained from $\chi^{2}$-statistics. + significant at 10 percent, ${ }^{*}$ significant at 5 percent, ${ }^{* *}$ significant at 1 percent level. 
Table 5: Institutional Heterogeneity in Child-to-Parent Time Regressions

\begin{tabular}{|c|c|c|c|c|c|c|}
\hline & \multicolumn{3}{|c|}{ Help to parents } & \multicolumn{3}{|c|}{ Frequency of help } \\
\hline & $\begin{array}{c}\text { Extended } \\
\text { Family } \\
\text { Countries }\end{array}$ & $\begin{array}{c}\text { Nuclear } \\
\text { Family } \\
\text { Countries }\end{array}$ & $\begin{array}{l}\text { Autonomy } \\
\text { Countries }\end{array}$ & $\begin{array}{c}\text { Extended } \\
\text { Family } \\
\text { Countries }\end{array}$ & $\begin{array}{c}\text { Nuclear } \\
\text { Family } \\
\text { Countries }\end{array}$ & $\begin{array}{l}\text { Autonomy } \\
\text { Countries }\end{array}$ \\
\hline \multicolumn{7}{|l|}{ Child } \\
\hline Age & $\begin{array}{c}0.006 \\
(0.019)\end{array}$ & $\begin{array}{c}0.016^{*} \\
(0.008)\end{array}$ & $\begin{array}{c}0.013 \\
(0.015)\end{array}$ & $\begin{array}{c}0.000 \\
(0.017)\end{array}$ & $\begin{array}{c}0.016^{*} \\
(0.008)\end{array}$ & $\begin{array}{c}0.018 \\
(0.014)\end{array}$ \\
\hline Female & $\begin{array}{c}0.012 \\
(0.180)\end{array}$ & $\begin{array}{l}0.201^{* *} \\
(0.059)\end{array}$ & $\begin{array}{c}-0.271^{* *} \\
(0.100)\end{array}$ & $\begin{array}{c}0.081 \\
(0.188)\end{array}$ & $\begin{array}{l}0.237^{* *} \\
(0.055)\end{array}$ & $\begin{array}{l}-0.194^{*} \\
(0.094)\end{array}$ \\
\hline Married & $\begin{array}{c}0.393 \\
(0.313)\end{array}$ & $\begin{array}{r}-0.133+ \\
(0.072)\end{array}$ & $\begin{array}{l}-0.088 \\
(0.127)\end{array}$ & $\begin{array}{c}0.399 \\
(0.296)\end{array}$ & $\begin{array}{l}-0.135^{*} \\
(0.068)\end{array}$ & $\begin{array}{l}-0.065 \\
(0.115)\end{array}$ \\
\hline Grandchildren & $\begin{array}{c}0.200 \\
(0.286)\end{array}$ & $\begin{array}{c}0.055 \\
(0.081)\end{array}$ & $\begin{array}{l}-0.031 \\
(0.144)\end{array}$ & $\begin{array}{c}0.188 \\
(0.274)\end{array}$ & $\begin{array}{c}0.035 \\
(0.079)\end{array}$ & $\begin{array}{l}-0.068 \\
(0.135)\end{array}$ \\
\hline Firstborn & $\begin{array}{c}-1.008^{* *} \\
(0.200)\end{array}$ & $\begin{array}{c}-0.479^{* *} \\
(0.072)\end{array}$ & $\begin{array}{c}-0.643^{* *} \\
(0.140)\end{array}$ & $\begin{array}{c}-0.960^{* *} \\
(0.205)\end{array}$ & $\begin{array}{c}-0.453^{* *} \\
(0.069)\end{array}$ & $\begin{array}{c}-0.657^{* *} \\
(0.127)\end{array}$ \\
\hline Second-born & $\begin{array}{c}-0.943^{* *} \\
(0.210)\end{array}$ & $\begin{array}{c}-0.421^{* *} \\
(0.074)\end{array}$ & $\begin{array}{c}-0.599^{* *} \\
(0.140)\end{array}$ & $\begin{array}{c}-0.906^{* *} \\
(0.210)\end{array}$ & $\begin{array}{c}-0.410^{* *} \\
(0.071)\end{array}$ & $\begin{array}{c}-0.554^{* *} \\
(0.134)\end{array}$ \\
\hline Parent & & & & & & \\
\hline Age & $\begin{array}{c}0.027 \\
(0.018)\end{array}$ & $\begin{array}{l}0.014+ \\
(0.008)\end{array}$ & $\begin{array}{c}0.021 \\
(0.013)\end{array}$ & $\begin{array}{l}0.030+ \\
(0.018)\end{array}$ & $\begin{array}{l}0.015^{*} \\
(0.007)\end{array}$ & $\begin{array}{c}0.017 \\
(0.012)\end{array}$ \\
\hline Female & $\begin{array}{l}0.766^{* *} \\
(0.276)\end{array}$ & $\begin{array}{c}0.044 \\
(0.086)\end{array}$ & $\begin{array}{l}0.602^{* *} \\
(0.156)\end{array}$ & $\begin{array}{l}0.729^{*} \\
(0.295)\end{array}$ & $\begin{array}{c}0.064 \\
(0.081)\end{array}$ & $\begin{array}{l}0.553^{* *} \\
(0.155)\end{array}$ \\
\hline Married & $\begin{array}{c}0.020 \\
(0.216)\end{array}$ & $\begin{array}{c}-0.569^{* *} \\
(0.083)\end{array}$ & $\begin{array}{l}-0.352^{*} \\
(0.146)\end{array}$ & $\begin{array}{l}-0.015 \\
(0.214)\end{array}$ & $\begin{array}{c}-0.554^{* *} \\
(0.079)\end{array}$ & $\begin{array}{l}-0.323^{*} \\
(0.141)\end{array}$ \\
\hline Limited activities & $\begin{array}{c}0.232 \\
(0.220)\end{array}$ & $\begin{array}{c}0.404^{* *} \\
(0.085)\end{array}$ & $\begin{array}{c}0.162 \\
(0.152)\end{array}$ & $\begin{array}{c}0.286 \\
(0.213)\end{array}$ & $\begin{array}{l}0.410^{* *} \\
(0.082)\end{array}$ & $\begin{array}{c}0.160 \\
(0.143)\end{array}$ \\
\hline $\begin{array}{l}\text { Severely } \\
\text { limited activities }\end{array}$ & $\begin{array}{c}0.870^{* *} \\
(0.284)\end{array}$ & $\begin{array}{c}0.814^{* *} \\
(0.100)\end{array}$ & $\begin{array}{c}0.556^{* *} \\
(0.196)\end{array}$ & $\begin{array}{c}0.884^{* *} \\
(0.262)\end{array}$ & $\begin{array}{c}0.842^{* *} \\
(0.096)\end{array}$ & $\begin{array}{c}0.638^{* *} \\
(0.189)\end{array}$ \\
\hline P-value of equality test ${ }^{a}$ & 0.41 & 0.06 & 0.50 & 0.54 & 0.16 & 0.13 \\
\hline Pseudo $R^{2}$ & 0.27 & 0.22 & 0.23 & 0.23 & 0.17 & 0.17 \\
\hline Observations & 1,051 & 4,371 & 1,319 & 1,051 & 4,371 & 1,319 \\
\hline
\end{tabular}

Notes: Columns (1)-(3) report estimates from probit regressions, columns (4)-(6) report estimates from ordered probit regressions. Extended family countries: Italy and Spain. Nuclear family countries: Austria, Belgium, Greece, France and the Netherlands. Autonomy countries: Denmark and Sweden. The reference categories for non-scaled variables are male, not married, no grandchildren, being an only child, male parent, unmarried parent, and parent has not been limited for the past six month because of a health problem in usual daily activities. Robust standard errors at the family level in parentheses. All regressions also control for a maximum set of highest educational degree variables for adult children and parents. ${ }^{a}$ Figures are p-values of the test that the estimated coefficients of being firstborn and second-born are equal and are obtained from $\chi^{2}$-statistics. + significant at 10 percent, ${ }^{*}$ significant at 5 percent, ${ }^{* *}$ significant at 1 percent level. 
Table 6: Sibship Sex Composition in Child-to-Parent Time Regressions (Help to Parents)

\begin{tabular}{|c|c|c|c|c|}
\hline & All Countries & $\begin{array}{c}\text { Extended Family } \\
\text { Countries }\end{array}$ & $\begin{array}{c}\text { Nuclear Family } \\
\text { Countries }\end{array}$ & $\begin{array}{l}\text { Autonomy } \\
\text { Countries } \\
\end{array}$ \\
\hline \multicolumn{5}{|l|}{ Child } \\
\hline Age & $\begin{array}{l}0.016^{*} \\
(0.007)\end{array}$ & $\begin{array}{c}0.006 \\
(0.018)\end{array}$ & $\begin{array}{c}0.017^{*} \\
(0.008)\end{array}$ & $\begin{array}{c}0.012 \\
(0.014)\end{array}$ \\
\hline Female & $\begin{array}{c}0.039 \\
(0.079)\end{array}$ & $\begin{array}{c}0.250 \\
(0.236)\end{array}$ & $\begin{array}{c}0.115 \\
(0.094)\end{array}$ & $\begin{array}{r}-0.398+ \\
(0.206)\end{array}$ \\
\hline Married & $\begin{array}{l}-0.100 \\
(0.061)\end{array}$ & $\begin{array}{c}0.463 \\
(0.312)\end{array}$ & $\begin{array}{r}-0.137+ \\
(0.072)\end{array}$ & $\begin{array}{l}-0.088 \\
(0.129)\end{array}$ \\
\hline Grandchildren & $\begin{array}{c}0.039 \\
(0.068)\end{array}$ & $\begin{array}{c}0.210 \\
(0.283)\end{array}$ & $\begin{array}{c}0.045 \\
(0.081)\end{array}$ & $\begin{array}{l}-0.038 \\
(0.147)\end{array}$ \\
\hline Adam of Adam-Benjamin & $\begin{array}{c}-0.624^{* *} \\
(0.115)\end{array}$ & $\begin{array}{l}-0.539 \\
(0.340)\end{array}$ & $\begin{array}{c}-0.644^{* *} \\
(0.146)\end{array}$ & $\begin{array}{c}-0.824^{* *} \\
(0.229)\end{array}$ \\
\hline Adam of Adam-Betty & $\begin{array}{c}-0.489^{* *} \\
(0.100)\end{array}$ & $\begin{array}{c}-0.712^{*} \\
(0.316)\end{array}$ & $\begin{array}{c}-0.396^{* *} \\
(0.121)\end{array}$ & $\begin{array}{c}-0.751^{* *} \\
(0.222)\end{array}$ \\
\hline Alice of Alice-Betty & $\begin{array}{c}-0.419^{* *} \\
(0.099)\end{array}$ & $\begin{array}{c}-1.084^{* *} \\
(0.329)\end{array}$ & $\begin{array}{c}-0.232^{*} \\
(0.114)\end{array}$ & $\begin{array}{c}-1.171^{* *} \\
(0.304)\end{array}$ \\
\hline Alice of Alice-Benjamin & $\begin{array}{c}-0.677^{* *} \\
(0.105)\end{array}$ & & $\begin{array}{c}-0.751^{* *} \\
(0.134)\end{array}$ & $\begin{array}{l}-0.148 \\
(0.223)\end{array}$ \\
\hline Benjamin of Adam-Benjamin & $\begin{array}{c}-0.559^{* *} \\
(0.115)\end{array}$ & $\begin{array}{l}-0.458 \\
(0.341)\end{array}$ & $\begin{array}{c}-0.578^{* *} \\
(0.146)\end{array}$ & $\begin{array}{c}-0.783^{* *} \\
(0.223)\end{array}$ \\
\hline Betty of Adam-Betty & $\begin{array}{c}-0.472^{* *} \\
(0.100)\end{array}$ & $\begin{array}{c}-0.915^{* *} \\
(0.315)\end{array}$ & $\begin{array}{c}-0.458^{* *} \\
(0.120)\end{array}$ & $\begin{array}{c}-0.321 \\
(0.236)\end{array}$ \\
\hline Betty of Alice-Betty & $\begin{array}{c}-0.358^{* *} \\
(0.100)\end{array}$ & $\begin{array}{c}-1.005^{* *} \\
(0.343)\end{array}$ & $\begin{array}{l}-0.172 \\
(0.115)\end{array}$ & $\begin{array}{c}-1.114^{* *} \\
(0.298)\end{array}$ \\
\hline Benjamin of Alice-Benjamin & $\begin{array}{c}-0.559^{* *} \\
(0.108)\end{array}$ & & $\begin{array}{c}-0.562^{* *} \\
(0.136)\end{array}$ & $\begin{array}{l}-0.496^{*} \\
(0.215)\end{array}$ \\
\hline Parent & & & & \\
\hline Age & $\begin{array}{l}0.015^{*} \\
(0.006)\end{array}$ & $\begin{array}{c}0.029 \\
(0.019)\end{array}$ & $\begin{array}{l}0.013+ \\
(0.008)\end{array}$ & $\begin{array}{l}0.024+ \\
(0.013)\end{array}$ \\
\hline Female & $\begin{array}{c}0.215^{* *} \\
(0.072)\end{array}$ & $\begin{array}{c}0.813^{* *} \\
(0.263)\end{array}$ & $\begin{array}{c}0.039 \\
(0.087)\end{array}$ & $\begin{array}{c}0.639^{* *} \\
(0.158)\end{array}$ \\
\hline Married & $\begin{array}{c}-0.456^{* *} \\
(0.069)\end{array}$ & $\begin{array}{l}-0.046 \\
(0.215)\end{array}$ & $\begin{array}{c}-0.568^{* *} \\
(0.084)\end{array}$ & $\begin{array}{c}-0.356^{*} \\
(0.146)\end{array}$ \\
\hline Limited activities & $\begin{array}{l}0.339 * * \\
(0.070)\end{array}$ & $\begin{array}{c}0.277 \\
(0.221)\end{array}$ & $\begin{array}{c}0.414^{* *} \\
(0.086)\end{array}$ & $\begin{array}{c}0.160 \\
(0.153)\end{array}$ \\
\hline $\begin{array}{l}\text { Severely } \\
\text { limited activities }\end{array}$ & $\begin{array}{c}0.754^{* *} \\
(0.084)\end{array}$ & $\begin{array}{c}0.935^{* *} \\
(0.290)\end{array}$ & $\begin{array}{c}0.828^{* *} \\
(0.100)\end{array}$ & $\begin{array}{c}0.547^{* *} \\
(0.195)\end{array}$ \\
\hline $\begin{array}{l}\text { Pseudo } R^{2} \\
\text { Observations }\end{array}$ & $\begin{array}{c}0.22 \\
6,741\end{array}$ & $\begin{array}{c}0.25 \\
869\end{array}$ & $\begin{array}{c}0.23 \\
4,371\end{array}$ & $\begin{array}{c}0.25 \\
1,319\end{array}$ \\
\hline
\end{tabular}

Notes: The dependent variable is help to parents. Estimates from probit regressions. Extended family countries: Italy and Spain. Nuclear family countries: Germany, France, Austria, Greece, Belgium and the Netherlands. Autonomy countries: Sweden and Denmark. The reference categories for non-scaled variables are male, not married, no grandchildren, being an only child, male parent, unmarried parent, and parent has not been limited for the past six month because of a health problem in usual daily activities. Robust standard errors at the family level in parentheses. All regressions also control for a maximum set of highest educational degree variables for adult children and parents. Regressions in columns 1 and 2 also include a maximum set of country dummy variables. In the extended family countries two child type coefficients and 182 observations are dropped from the regression because they predict failure perfectly. + significant at 10 percent, ${ }^{*}$ significant at 5 percent, ${ }^{* *}$ significant at 1 percent level. 
Table 7: Sibship Sex Composition in Child-to-Parent Time Regressions (Frequency of Help)

\begin{tabular}{|c|c|c|c|c|}
\hline & All Countries & $\begin{array}{c}\text { Extended Family } \\
\text { Countries }\end{array}$ & $\begin{array}{c}\text { Nuclear Family } \\
\text { Countries }\end{array}$ & $\begin{array}{l}\text { Autonomy } \\
\text { Countries } \\
\end{array}$ \\
\hline \multicolumn{5}{|l|}{ Child } \\
\hline \multirow[t]{2}{*}{ Age } & $0.016^{*}$ & -0.004 & $0.016^{*}$ & 0.016 \\
\hline & $(0.006)$ & $(0.018)$ & $(0.008)$ & $(0.014)$ \\
\hline \multirow[t]{2}{*}{ Female } & 0.118 & 0.354 & $0.177^{*}$ & -0.233 \\
\hline & $(0.074)$ & $(0.231)$ & $(0.088)$ & $(0.190)$ \\
\hline \multirow[t]{2}{*}{ Married } & $-0.099+$ & 0.417 & $-0.138^{*}$ & -0.059 \\
\hline & $(0.057)$ & $(0.308)$ & $(0.068)$ & $(0.118)$ \\
\hline \multirow[t]{2}{*}{ Grandchildren } & 0.029 & 0.211 & 0.027 & -0.073 \\
\hline & $(0.066)$ & $(0.284)$ & $(0.078)$ & $(0.137)$ \\
\hline \multirow[t]{2}{*}{ Adam of Adam-Benjamin } & $-0.589^{* *}$ & -0.435 & $-0.632^{* *}$ & $-0.779 * *$ \\
\hline & $(0.110)$ & $(0.350)$ & $(0.139)$ & $(0.209)$ \\
\hline \multirow[t]{2}{*}{ Adam of Adam-Betty } & $-0.420 * *$ & $-0.709^{*}$ & $-0.323^{* *}$ & $-0.680 * *$ \\
\hline & $(0.096)$ & $(0.313)$ & $(0.116)$ & $(0.208)$ \\
\hline \multirow[t]{2}{*}{ Alice of Alice-Betty } & $-0.421^{* *}$ & $-1.153^{* *}$ & $-0.238^{*}$ & $-1.258^{* *}$ \\
\hline & $(0.095)$ & $(0.368)$ & $(0.108)$ & $(0.287)$ \\
\hline \multirow[t]{2}{*}{ Alice of Alice-Benjamin } & $-0.697^{* *}$ & & $-0.740^{* *}$ & -0.264 \\
\hline & $(0.103)$ & & $(0.133)$ & $(0.207)$ \\
\hline \multirow[t]{2}{*}{ Benjamin of Adam-Benjamin } & $-0.527^{* *}$ & -0.456 & $-0.564^{* *}$ & $-0.706^{* *}$ \\
\hline & $(0.111)$ & $(0.344)$ & $(0.140)$ & $(0.215)$ \\
\hline \multirow[t]{2}{*}{ Betty of Adam-Betty } & $-0.425^{* *}$ & $-0.921^{* *}$ & $-0.399 * *$ & -0.313 \\
\hline & $(0.099)$ & $(0.326)$ & $(0.118)$ & $(0.237)$ \\
\hline \multirow[t]{2}{*}{ Betty of Alice-Betty } & $-0.408^{* *}$ & $-1.117^{* *}$ & $-0.238^{*}$ & $-1.156^{* *}$ \\
\hline & $(0.095)$ & $(0.383)$ & $(0.108)$ & $(0.297)$ \\
\hline \multirow[t]{2}{*}{ Benjamin of Alice-Benjamin } & $-0.519^{* *}$ & & $-0.528^{* *}$ & $-0.404^{*}$ \\
\hline & $(0.103)$ & & $(0.131)$ & $(0.198)$ \\
\hline \multicolumn{5}{|l|}{ Parent } \\
\hline \multirow[t]{2}{*}{ Age } & $0.016^{* *}$ & $0.035^{*}$ & $0.014+$ & 0.020 \\
\hline & $(0.006)$ & $(0.018)$ & $(0.007)$ & $(0.012)$ \\
\hline \multirow[t]{2}{*}{ Female } & $0.212^{* *}$ & $0.786^{* *}$ & 0.058 & $0.588^{* *}$ \\
\hline & $(0.070)$ & $(0.286)$ & $(0.083)$ & $(0.157)$ \\
\hline \multirow[t]{2}{*}{ Married } & $-0.444^{* *}$ & -0.070 & $-0.551^{* *}$ & $-0.329^{*}$ \\
\hline & $(0.066)$ & $(0.211)$ & $(0.080)$ & $(0.141)$ \\
\hline \multirow[t]{2}{*}{ Limited activities } & $0.791^{* *}$ & $0.908^{* *}$ & $0.853^{* *}$ & $0.636^{* *}$ \\
\hline & $(0.080)$ & $(0.273)$ & $(0.096)$ & $(0.188)$ \\
\hline \multicolumn{5}{|l|}{ Severely } \\
\hline \multirow[t]{2}{*}{ limited activities } & $0.352^{* *}$ & 0.273 & $0.419^{* *}$ & 0.162 \\
\hline & $(0.068)$ & $(0.224)$ & $(0.083)$ & $(0.143)$ \\
\hline Pseudo $R^{2}$ & 0.17 & 0.22 & 0.18 & 0.19 \\
\hline Observations & 6,741 & 869 & 4,371 & 1,319 \\
\hline
\end{tabular}

Notes: The dependent variable is the frequency of help to parents (five categories). Estimates from ordered probit regressions. Extended family countries: Italy and Spain. Nuclear Family Countries: Germany, France, Austria, Greece, Belgium and the Netherlands. Autonomy countries: Sweden and Denmark. The reference categories for non-scaled variables are male, not married, no grandchildren, being an only child, male parent, unmarried parent, and parent has not been limited for the past six month because of a health problem in usual daily activities. Robust standard errors at the family level in parentheses. All regressions also control for a maximum set of highest educational degree variables for adult children and parents. Regressions in columns 1 and 2 also include a maximum set of country dummy variables. In the extended family countries two child type coefficients and 182 observations are dropped from the regression because they predict failure perfectly. + significant at 10 percent, ${ }^{*}$ significant at 5 percent, ${ }^{* *}$ significant at 1 percent level. 
Appendix 1: Summary Statistics of Outcome Variables

\begin{tabular}{|c|c|c|c|c|c|c|c|c|c|c|c|}
\hline & $\begin{array}{c}\text { All } \\
\text { countries }\end{array}$ & Italy & Spain & Germany & France & Austria & Greece & Belgium & $\begin{array}{c}\text { Nether- } \\
\text { lands }\end{array}$ & Sweden & Denmark \\
\hline \multicolumn{12}{|c|}{ Child-parent geographic distance } \\
\hline Same house or household & 0.136 & 0.331 & 0.240 & 0.151 & 0.059 & 0.165 & 0.261 & 0.081 & 0.027 & 0.015 & 0.023 \\
\hline Less than 1 kilometre away & 0.151 & 0.135 & 0.284 & 0.120 & 0.109 & 0.130 & 0.183 & 0.172 & 0.162 & 0.115 & 0.108 \\
\hline 1-5 kilometres away & 0.192 & 0.177 & 0.181 & 0.176 & 0.153 & 0.177 & 0.159 & 0.234 & 0.269 & 0.205 & 0.168 \\
\hline 5-100 kilometres away & 0.356 & 0.265 & 0.191 & 0.346 & 0.404 & 0.357 & 0.239 & 0.446 & 0.415 & 0.411 & 0.500 \\
\hline More than 100 kilometres away & 0.165 & 0.092 & 0.105 & 0.207 & 0.275 & 0.172 & 0.159 & 0.067 & 0.127 & 0.255 & 0.200 \\
\hline Number of observations & 9,707 & 966 & 735 & 1,114 & 920 & 869 & 1,173 & 1,217 & 962 & 1,151 & 600 \\
\hline \multicolumn{12}{|l|}{ Time transfers to parents } \\
\hline Help to parents & $\begin{array}{c}0.093 \\
(0.290)\end{array}$ & $\begin{array}{c}0.032 \\
(0.177)\end{array}$ & $\begin{array}{c}0.057 \\
(0.231)\end{array}$ & $\begin{array}{c}0.158 \\
(0.365)\end{array}$ & $\begin{array}{c}0.080 \\
(0.271)\end{array}$ & $\begin{array}{c}0.122 \\
(0.328)\end{array}$ & $\begin{array}{c}0.144 \\
(0.352)\end{array}$ & $\begin{array}{c}0.081 \\
(0.273)\end{array}$ & $\begin{array}{c}0.041 \\
(0.199)\end{array}$ & $\begin{array}{c}0.083 \\
(0.277)\end{array}$ & $\begin{array}{c}0.125 \\
(0.331)\end{array}$ \\
\hline \multicolumn{12}{|l|}{ Frequency of help } \\
\hline No help received & 0.907 & 0.968 & 0.944 & 0.842 & 0.920 & 0.878 & 0.856 & 0.919 & 0.959 & 0.917 & 0.875 \\
\hline Less often than every month & 0.020 & 0.000 & 0.004 & 0.031 & 0.010 & 0.021 & 0.025 & 0.012 & 0.020 & 0.029 & 0.044 \\
\hline Almost every month & 0.021 & 0.012 & 0.009 & 0.035 & 0.015 & 0.027 & 0.035 & 0.012 & 0.006 & 0.024 & 0.039 \\
\hline Almost every week & 0.037 & 0.012 & 0.015 & 0.070 & 0.032 & 0.055 & 0.059 & 0.040 & 0.011 & 0.026 & 0.037 \\
\hline Almost daily & 0.015 & 0.009 & 0.028 & 0.021 & 0.023 & 0.018 & 0.026 & 0.017 & 0.004 & 0.005 & 0.005 \\
\hline Number of observations & 6,741 & 591 & 460 & 795 & 729 & 597 & 693 & 826 & 731 & 887 & 432 \\
\hline
\end{tabular}

Notes: Figures are means with standard deviations in parentheses. 
Appendix 2: Summary Statistics of Explanatory Variables

\begin{tabular}{|c|c|c|c|c|c|c|c|c|c|c|c|}
\hline & $\begin{array}{c}\text { All } \\
\text { countries }\end{array}$ & Italy & Spain & Germany & France & Austria & Greece & Belgium & $\begin{array}{c}\text { Nether- } \\
\text { lands }\end{array}$ & Sweden & Denmark \\
\hline \multicolumn{12}{|l|}{ Main explanatory variables } \\
\hline \multicolumn{12}{|l|}{ Child } \\
\hline Age & $\begin{array}{l}41.99 \\
(8.32)\end{array}$ & $\begin{array}{l}40.16 \\
(7.45)\end{array}$ & $\begin{array}{l}42.39 \\
(8.38)\end{array}$ & $\begin{array}{l}41.99 \\
(8.28)\end{array}$ & $\begin{array}{l}42.39 \\
(8.55)\end{array}$ & $\begin{array}{l}42.25 \\
(8.01)\end{array}$ & $\begin{array}{l}42.98 \\
(8.24)\end{array}$ & $\begin{array}{l}41.89 \\
(8.42)\end{array}$ & $\begin{array}{l}39.78 \\
(7.48)\end{array}$ & $\begin{array}{l}42.82 \\
(8.76)\end{array}$ & $\begin{array}{l}43.73 \\
(8.91)\end{array}$ \\
\hline Female & $\begin{array}{c}0.500 \\
(0.500)\end{array}$ & $\begin{array}{c}0.502 \\
(0.500)\end{array}$ & $\begin{array}{c}0.488 \\
(0.500)\end{array}$ & $\begin{array}{c}0.505 \\
(0.500)\end{array}$ & $\begin{array}{c}0.505 \\
(0.500)\end{array}$ & $\begin{array}{c}0.524 \\
(0.500)\end{array}$ & $\begin{array}{c}0.480 \\
(0.500)\end{array}$ & $\begin{array}{c}0.500 \\
(0.500)\end{array}$ & $\begin{array}{c}0.490 \\
(0.500)\end{array}$ & $\begin{array}{c}0.517 \\
(0.500)\end{array}$ & $\begin{array}{c}0.495 \\
(0.500)\end{array}$ \\
\hline Married & $\begin{array}{c}0.645 \\
(0.479)\end{array}$ & $\begin{array}{c}0.654 \\
(0.476)\end{array}$ & $\begin{array}{c}0.737 \\
(0.440)\end{array}$ & $\begin{array}{c}0.630 \\
(0.483)\end{array}$ & $\begin{array}{c}0.635 \\
(0.482)\end{array}$ & $\begin{array}{c}0.613 \\
(0.487)\end{array}$ & $\begin{array}{c}0.765 \\
(0.424)\end{array}$ & $\begin{array}{c}0.646 \\
(0.478)\end{array}$ & $\begin{array}{c}0.647 \\
(0.478)\end{array}$ & $\begin{array}{c}0.517 \\
(0.499)\end{array}$ & $\begin{array}{c}0.613 \\
(0.487)\end{array}$ \\
\hline Grandchildren & $\begin{array}{c}0.719 \\
(0.450)\end{array}$ & $\begin{array}{c}0.588 \\
(0.492)\end{array}$ & $\begin{array}{c}0.728 \\
(0.445)\end{array}$ & $\begin{array}{c}0.694 \\
(0.461)\end{array}$ & $\begin{array}{c}0.767 \\
(0.422)\end{array}$ & $\begin{array}{c}0.694 \\
(0.461)\end{array}$ & $\begin{array}{c}0.757 \\
(0.429)\end{array}$ & $\begin{array}{c}0.745 \\
(0.436)\end{array}$ & $\begin{array}{c}0.664 \\
(0.472)\end{array}$ & $\begin{array}{c}0.778 \\
(0.416)\end{array}$ & $\begin{array}{c}0.768 \\
(0.422)\end{array}$ \\
\hline Firstborn & $\begin{array}{c}0.387 \\
(0.487)\end{array}$ & $\begin{array}{c}0.383 \\
(0.486)\end{array}$ & $\begin{array}{c}0.389 \\
(0.487)\end{array}$ & $\begin{array}{c}0.360 \\
(0.480)\end{array}$ & $\begin{array}{c}0.360 \\
(0.480)\end{array}$ & $\begin{array}{c}0.364 \\
(0.481)\end{array}$ & $\begin{array}{c}0.415 \\
(0.493)\end{array}$ & $\begin{array}{c}0.355 \\
(0.479)\end{array}$ & $\begin{array}{c}0.425 \\
(0.495)\end{array}$ & $\begin{array}{c}0.414 \\
(0.493)\end{array}$ & $\begin{array}{c}0.420 \\
(0.494)\end{array}$ \\
\hline Second-born & $\begin{array}{c}0.387 \\
(0.487)\end{array}$ & $\begin{array}{c}0.383 \\
(0.486)\end{array}$ & $\begin{array}{c}0.389 \\
(0.487)\end{array}$ & $\begin{array}{c}0.360 \\
(0.480)\end{array}$ & $\begin{array}{c}0.360 \\
(0.480)\end{array}$ & $\begin{array}{c}0.364 \\
(0.481)\end{array}$ & $\begin{array}{c}0.415 \\
(0.493)\end{array}$ & $\begin{array}{c}0.355 \\
(0.479)\end{array}$ & $\begin{array}{c}0.425 \\
(0.495)\end{array}$ & $\begin{array}{c}0.414 \\
(0.493)\end{array}$ & $\begin{array}{c}0.420 \\
(0.494)\end{array}$ \\
\hline Only child & $\begin{array}{c}0.225 \\
(0.418)\end{array}$ & $\begin{array}{c}0.234 \\
(0.424)\end{array}$ & $\begin{array}{c}0.222 \\
(0.416)\end{array}$ & $\begin{array}{c}0.282 \\
(0.450)\end{array}$ & $\begin{array}{c}0.280 \\
(0.449)\end{array}$ & $\begin{array}{c}0.273 \\
(0.446)\end{array}$ & $\begin{array}{c}0.170 \\
(0.375)\end{array}$ & $\begin{array}{c}0.290 \\
(0.454)\end{array}$ & $\begin{array}{c}0.150 \\
(0.357)\end{array}$ & $\begin{array}{c}0.171 \\
(0.377)\end{array}$ & $\begin{array}{c}0.160 \\
(0.367)\end{array}$ \\
\hline \multicolumn{12}{|l|}{ Parent } \\
\hline Age & $\begin{array}{l}69.64 \\
(8.99)\end{array}$ & $\begin{array}{l}68.52 \\
(7.85)\end{array}$ & $\begin{array}{l}71.91 \\
(8.90)\end{array}$ & $\begin{array}{l}68.77 \\
(8.67)\end{array}$ & $\begin{array}{l}69.42 \\
(9.21)\end{array}$ & $\begin{array}{l}69.11 \\
(8.55)\end{array}$ & $\begin{array}{l}71.68 \\
(8.94)\end{array}$ & $\begin{array}{l}68.99 \\
(9.11)\end{array}$ & $\begin{array}{l}67.66 \\
(8.92)\end{array}$ & $\begin{array}{l}70.34 \\
(9.29)\end{array}$ & $\begin{array}{l}70.52 \\
(9.62)\end{array}$ \\
\hline Female & $\begin{array}{c}0.593 \\
(0.491)\end{array}$ & $\begin{array}{c}0.611 \\
(0.488)\end{array}$ & $\begin{array}{c}0.641 \\
(0.480)\end{array}$ & $\begin{array}{c}0.591 \\
(0.492)\end{array}$ & $\begin{array}{c}0.622 \\
(0.485)\end{array}$ & $\begin{array}{c}0.612 \\
(0.487)\end{array}$ & $\begin{array}{c}0.646 \\
(0.478)\end{array}$ & $\begin{array}{c}0.500 \\
(0.500)\end{array}$ & $\begin{array}{c}0.536 \\
(0.499)\end{array}$ & $\begin{array}{c}0.586 \\
(0.493)\end{array}$ & $\begin{array}{c}0.620 \\
(0.486)\end{array}$ \\
\hline Married & $\begin{array}{c}0.597 \\
(0.490)\end{array}$ & $\begin{array}{c}0.710 \\
(0.454)\end{array}$ & $\begin{array}{c}0.635 \\
(0.482)\end{array}$ & $\begin{array}{c}0.676 \\
(0.468)\end{array}$ & $\begin{array}{c}0.528 \\
(0.499)\end{array}$ & $\begin{array}{c}0.486 \\
(0.500)\end{array}$ & $\begin{array}{c}0.460 \\
(0.499)\end{array}$ & $\begin{array}{c}0.592 \\
(0.492)\end{array}$ & $\begin{array}{c}0.719 \\
(0.499)\end{array}$ & $\begin{array}{c}0.656 \\
(0.475)\end{array}$ & $\begin{array}{c}0.458 \\
(0.499)\end{array}$ \\
\hline \multicolumn{12}{|c|}{ Limited because of a health problem } \\
\hline Not limited & $\begin{array}{c}0.527 \\
(0.499)\end{array}$ & $\begin{array}{c}0.555 \\
(0.497)\end{array}$ & $\begin{array}{c}0.503 \\
(0.500)\end{array}$ & $\begin{array}{c}0.431 \\
(0.496)\end{array}$ & $\begin{array}{c}0.577 \\
(0.494)\end{array}$ & $\begin{array}{c}0.489 \\
(0.500)\end{array}$ & $\begin{array}{c}0.549 \\
(0.499)\end{array}$ & $\begin{array}{c}0.556 \\
(0.497)\end{array}$ & $\begin{array}{c}0.554 \\
(0.497)\end{array}$ & $\begin{array}{c}0.540 \\
(0.499)\end{array}$ & $\begin{array}{c}0.505 \\
(0.500)\end{array}$ \\
\hline Limited, but not severely & $\begin{array}{c}0.322 \\
(0.467)\end{array}$ & $\begin{array}{c}0.302 \\
(0.459)\end{array}$ & $\begin{array}{c}0.435 \\
(0.496)\end{array}$ & $\begin{array}{c}0.364 \\
(0.481)\end{array}$ & $\begin{array}{c}0.259 \\
(0.440)\end{array}$ & $\begin{array}{c}0.360 \\
(0.480)\end{array}$ & $\begin{array}{c}0.336 \\
(0.473)\end{array}$ & $\begin{array}{c}0.271 \\
(0.445)\end{array}$ & $\begin{array}{c}0.266 \\
(0.442)\end{array}$ & $\begin{array}{c}0.317 \\
(0.466)\end{array}$ & $\begin{array}{c}0.350 \\
(0.477)\end{array}$ \\
\hline Severely limited & $\begin{array}{c}0.151 \\
(0.358)\end{array}$ & $\begin{array}{c}0.142 \\
(0.350)\end{array}$ & $\begin{array}{c}0.061 \\
(0.240)\end{array}$ & $\begin{array}{c}0.205 \\
(0.404)\end{array}$ & $\begin{array}{c}0.164 \\
(0.371)\end{array}$ & $\begin{array}{c}0.151 \\
(0.358)\end{array}$ & $\begin{array}{c}0.115 \\
(0.319)\end{array}$ & $\begin{array}{c}0.172 \\
(0.378)\end{array}$ & $\begin{array}{c}0.180 \\
(0.384)\end{array}$ & $\begin{array}{c}0.143 \\
(0.351)\end{array}$ & $\begin{array}{c}0.145 \\
(0.352)\end{array}$ \\
\hline Number of observations & 9,707 & 966 & 735 & 1,114 & 920 & 869 & 1,173 & 1,217 & 962 & 1,151 & 600 \\
\hline
\end{tabular}

Notes: Figures are means with standard deviations in parentheses. 
Appendix 3: Description of Variables

\begin{tabular}{|c|c|c|c|}
\hline Variable & Question in SHARE reads: & Variable in SHARE & Definition of variable \\
\hline $\begin{array}{l}\text { Outcome Variables } \\
\text { Child-parent } \\
\text { geographic distance }\end{array}$ & $\begin{array}{l}\text { "Please look at card } 5 . \text { Where } \\
\text { does [child name] live?" }\end{array}$ & $\begin{array}{l}\text { Card } 5 \text { : } \\
\text { (1) In the same household; } \\
\text { (2) In the same building; } \\
\text { (3) Less than } 1 \text { kilometre away; } \\
\text { (4) Between } 1 \text { and } 5 \mathrm{~km} \text { away; } \\
\text { (5) Between } 5 \text { and } 25 \mathrm{~km} \text { away; } \\
\text { (6) Between } 25 \text { and } 100 \mathrm{~km} \text { away; } \\
\text { (7) Between } 100 \text { and } 500 \mathrm{~km} \text { away; } \\
\text { (8) More than } 500 \mathrm{~km} \text { away; } \\
\text { (9) More than } 500 \mathrm{~km} \text { away in } \\
\text { another country. }\end{array}$ & $\begin{array}{l}\text { Variable has the following } \\
\text { five distance categories: } \\
\text { (1) In the same building } \\
\text { or household; } \\
\text { (2) Less than } 1 \mathrm{~km} \text { away; } \\
\text { (3) } 1 \text { to } 5 \mathrm{~km} \text { away; } \\
\text { (4) } 5 \text {-100 km away; } \\
\text { (5) More than } 100 \\
\text { kilometres away. }\end{array}$ \\
\hline Help to parents & $\begin{array}{l}\text { "Now please think of the last twelve } \\
\text { months. Has any family member } \\
\text { from outside the household, any } \\
\text { friend or neighbor given you [or] } \\
\text { [your] [husband/wife/partner] } \\
\text { any kind of help?" }\end{array}$ & (1) Yes; (5) No. & $\begin{array}{l}\text { Variable equals one if a } \\
\text { respondent indicates (1) } \\
\text { for a child, and zero } \\
\text { otherwise. }\end{array}$ \\
\hline Frequency of help & $\begin{array}{l}\text { "In the last twelve months, how } \\
\text { often altogether have you or } \\
\text { [or] [your] [husband/wife/partner] } \\
\text { received such help from this } \\
\text { person? Was it..." }\end{array}$ & $\begin{array}{l}\text { (1) Almost daily; } \\
\text { (2) Almost every week; } \\
\text { (3) Almost every month; } \\
\text { (4) Less often. }\end{array}$ & $\begin{array}{l}\text { Variable has the following } \\
\text { four help categories for } \\
\text { a particular child: } \\
\text { (1) Almost daily; } \\
\text { (2) Almost every week; } \\
\text { (3) Almost every month; } \\
\text { (4) Less often or } \\
\text { no help received. }\end{array}$ \\
\hline \multicolumn{4}{|c|}{ Explanatory Variables } \\
\hline Age & $\begin{array}{l}\text { "In which year was [child name] } \\
\text { born?" }\end{array}$ & & Age of child (in years). \\
\hline Female & "Is [child name] male or female?" & (1) Male; (2) Female. & Variable equals one if a \\
\hline
\end{tabular}




\begin{tabular}{|c|c|c|c|}
\hline Variables & Question in SHARE reads: & Variables in SHARE & Definition of variable \\
\hline & & & $\begin{array}{l}\text { respondent indicates }(2) \\
\text { for a child, and zero } \\
\text { otherwise. }\end{array}$ \\
\hline Married & $\begin{array}{l}\text { "Please look at card } 4 . \\
\text { What is the marital } \\
\text { status of [child name]?" }\end{array}$ & $\begin{array}{l}\text { (1) Married and living together } \\
\text { with spouse; (2) Registered } \\
\text { partnership; (3) Married, living } \\
\text { separated from spouse; (4) Never } \\
\text { married; (5) Divorced; } \\
\text { (6) Widowed. }\end{array}$ & $\begin{array}{l}\text { Variable equals one if a } \\
\text { respondent indicates (1) } \\
\text { for a child, and zero } \\
\text { otherwise. }\end{array}$ \\
\hline Grandchildren & $\begin{array}{l}\text { "How many children - } \\
\text { if any - does [child name] } \\
\text { have?" }\end{array}$ & & $\begin{array}{l}\text { Variable equals one if a } \\
\text { respondent indicates that } \\
\text { child has any children, and } \\
\text { zero otherwise. }\end{array}$ \\
\hline $\begin{array}{l}\text { Highest school } \\
\text { leaving certificate }\end{array}$ & $\begin{array}{l}\text { Please look at card } 2 . \\
\text { What is the highest } \\
\text { school leaving certificate } \\
\text { or school degree } \\
\text { [child name] has obtained? }\end{array}$ & $\begin{array}{l}\text { Card 2: } \\
\text { (1) Comprehensive school; } \\
\text { (2) Grammar school; } \\
\text { (3) Fee-paying grammar school; } \\
\text { (4) Sixth form College/ } \\
\text { Tertiary College } \\
\text { (5) Public or other private school } \\
\text { (6) Elementary school } \\
\text { (7) Secondary modern/ } \\
\text { secondary school } \\
\text { (8) Technical school (not college) } \\
\text { (95) No degree yet/still in school } \\
\text { (96) None } \\
\text { (97) Other type (also abroad). }\end{array}$ & $\begin{array}{l}\text { Information is used to } \\
\text { generate a maximum } \\
\text { set of educational dummy } \\
\text { variables for each child. }\end{array}$ \\
\hline $\begin{array}{l}\text { Parent } \\
\text { Age }\end{array}$ & $\begin{array}{l}\text { "In which month and year } \\
\text { were you born?" }\end{array}$ & & $\begin{array}{l}\text { Age of respondent } \\
\text { (in years). }\end{array}$ \\
\hline
\end{tabular}

Continued on next page 


\begin{tabular}{|c|c|c|c|}
\hline Variables & Question in SHARE reads: & Variables in SHARE & Definition of variable \\
\hline Female & "What is your sex?" & (1) Male; (2) Female. & $\begin{array}{l}\text { Variable equals one if } \\
\text { respondent indicates }(2) \text {, } \\
\text { and zero otherwise. }\end{array}$ \\
\hline Married & "What is your marital status?" & $\begin{array}{l}\text { (1) Married and living together } \\
\text { with spouse; (2) Registered } \\
\text { partnership; (3) Married, living } \\
\text { separated from spouse; (4) Never } \\
\text { married; (5) Divorced; (6) Widowed. }\end{array}$ & $\begin{array}{l}\text { Variable equals one if a } \\
\text { respondent indicates (1), } \\
\text { and zero otherwise. }\end{array}$ \\
\hline Limited activities & $\begin{array}{l}\text { "For the past six months at } \\
\text { least, to what extent have } \\
\text { you been limited because } \\
\text { of a health problem in } \\
\text { activities people usually do?" }\end{array}$ & $\begin{array}{l}\text { (1) Severely limited; (2) Limited, } \\
\text { but not severely; (3) Not limited. }\end{array}$ & $\begin{array}{l}\text { Information is used to } \\
\text { generate three dummy } \\
\text { variables. }\end{array}$ \\
\hline $\begin{array}{l}\text { Highest school } \\
\text { leaving certificate }\end{array}$ & $\begin{array}{l}\text { Please look at card } 2 . \\
\text { What is the highest } \\
\text { school leaving certificate } \\
\text { or school degree that you } \\
\text { have obtained? }\end{array}$ & See card 2 above. & $\begin{array}{l}\text { Information is used to } \\
\text { generate a maximum } \\
\text { set of educational dummy } \\
\text { variables. }\end{array}$ \\
\hline
\end{tabular}

